\title{
Strategic use of geotechnical data for maximised value added
}

\author{
CK Palleske Mine Design Engineering, Canada \\ KS Kalenchuk Mine Design Engineering, Canada \\ CD Hume Mine Design Engineering, Canada \\ WF Bawden Mine Design Engineering, Canada
}

\begin{abstract}
A sound geotechnical database forms the baseline for any geomechanical analysis or mine design. The level of detail of geotechnical information typically increases as a project moves from initial design stages through to construction and operation. This begins with core logging and outcrop mapping, enhanced by line mapping once additional excavation exposures are available. Lab testing, in situ stress testing and geophysical information may also be added to the database. The data collected early in a project often form the basis for decisions regarding mine design, method and sequencing. Once a project reaches the operation stage, the assumptions made about a site geomechanical model during earlier design phases must be verified.

This paper discusses how to maximise the use of geotechnical data that is routinely collected at each stage of project development by building an appropriate model for that phase of work. This includes the development of a site-specific ground behaviour model, which allows design criteria to be optimised for the conditions that are actually encountered. The use of ground behaviour data such as damage mapping, pull test results, falls of ground and overbreak for refining the geotechnical model are also discussed.
\end{abstract}

Keywords: geotechnical ground model, behaviour prediction

\section{Introduction}

A sound geotechnical database forms the baseline for any geomechanical analysis or mine design. Geotechnical data is traditionally obtained from geotechnical logging of core and mapping. Core logging and line mapping are arduous and time-consuming tasks that require highly trained personnel, who must remain focused and diligent in performing these tasks. Other data types include laboratory testing, in situ stress measurements, or ground response indicators such as (but not limited to) instrumentation data, pull test results, damage mapping observations and seismic data as the mining project matures. Geotechnical data is complemented by hydrogeology, geological data, structural geology data, ore reserve volumes etc. This paper discusses how to maximise the use of geotechnical data that is routinely collected at each stage of project development by building an appropriate model for that phase of work. Geotechnical analyses and design are as strong, or as weak, as the underlying geotechnical database.

\section{Expanding a database throughout the project life}

Geotechnical data collection begins during early scoping level studies and continues through prefeasibility and feasibility level investigations and onto construction and mine operations. A common topic of discussion (and debate) amongst geotechnical practitioners is the quantity of data considered sufficient for each of these varying phases of project life. Stacey (2009) provides guidelines for open pit studies (summarised in Table 1). Dunn et al. (2011) referenced several other guidelines that can be used to determine how much geotechnical information is required at each stage of a project. Haile (as cited in Dunn et al. 2011) describes levels of certainty in geotechnical data for resource and reserve delineation phase of a mining project and ultimately ties certainty to economic risk (shown in Table 2). These more general guidelines help to account 
for the complexity of a given orebody as well as the extent of existing information (as in a brownfield project), rather than setting stricter percentages of total drilling for inclusion in a geotechnical program.

Table 1 Descriptions of data types and levels of detail for varying project stages (Stacey 2009)

\begin{tabular}{|c|c|c|c|c|c|}
\hline \multirow[b]{2}{*}{ Data type } & \multirow[b]{2}{*}{ Conceptual } & \multicolumn{2}{|c|}{ Project stage } & \multirow[b]{2}{*}{$\begin{array}{l}\text { Design/ } \\
\text { construction }\end{array}$} & \multirow[b]{2}{*}{ Operations } \\
\hline & & Pre-feasibility & Feasibility & & \\
\hline $\begin{array}{l}\text { Geological } \\
\text { model }\end{array}$ & $\begin{array}{l}\text { Regional literature; } \\
\text { advanced } \\
\text { exploration mapping } \\
\text { and core logging; } \\
\text { database } \\
\text { established; initial } \\
\text { country rock model }\end{array}$ & $\begin{array}{l}\text { Mine scale outcrop } \\
\text { mapping and core logging; } \\
\text { enhance geological } \\
\text { database; initial 3D } \\
\text { geological model }\end{array}$ & $\begin{array}{l}\text { Infill drilling and } \\
\text { mapping; further } \\
\text { enhance geological } \\
\text { database and 3D model }\end{array}$ & $\begin{array}{l}\text { Targeting } \\
\text { drilling and } \\
\text { mapping; refine } \\
\text { geological } \\
\text { database and } \\
\text { 3D model }\end{array}$ & $\begin{array}{l}\text { Pit mapping and } \\
\text { drilling; further } \\
\text { refine geological } \\
\text { database and } 3 D \\
\text { model }\end{array}$ \\
\hline $\begin{array}{l}\text { Structural } \\
\text { model (major } \\
\text { features) }\end{array}$ & $\begin{array}{l}\text { Aerial photos and } \\
\text { initial ground } \\
\text { proofing }\end{array}$ & $\begin{array}{l}\text { Mine scale outcrop } \\
\text { mapping; targeted oriented } \\
\text { drilling; initial structural } \\
\text { model }\end{array}$ & $\begin{array}{l}\text { Trench mapping infill } \\
\text { oriented drilling; 3D } \\
\text { structural model }\end{array}$ & $\begin{array}{l}\text { Refined } \\
\text { interpetation of } \\
\text { 3D structural } \\
\text { model }\end{array}$ & $\begin{array}{l}\text { Structural } \\
\text { mapping on all } \\
\text { pit benches; } \\
\text { further refine 3D } \\
\text { model }\end{array}$ \\
\hline $\begin{array}{l}\text { Structural } \\
\text { model (fabric) }\end{array}$ & $\begin{array}{l}\text { Regional outcrop } \\
\text { mapping }\end{array}$ & $\begin{array}{l}\text { Mine scale outcrop } \\
\text { mapping; targeted oriented } \\
\text { drilling; database } \\
\text { established; initial } \\
\text { stereographic assessment } \\
\text { of fabric data; initial } \\
\text { structural domains } \\
\text { established }\end{array}$ & $\begin{array}{l}\text { Infill trench mapping } \\
\text { and oriented drilling; } \\
\text { enhance database; } \\
\text { advanced } \\
\text { stereographic } \\
\text { assessment of fabric } \\
\text { data; confirmation of } \\
\text { structural domains }\end{array}$ & $\begin{array}{l}\text { Refined interp. } \\
\text { of fabric data } \\
\text { and structural } \\
\text { domains }\end{array}$ & $\begin{array}{l}\text { Structural } \\
\text { mapping on all } \\
\text { pit benches; } \\
\text { further refine } \\
\text { fabric data and } \\
\text { structural } \\
\text { domains }\end{array}$ \\
\hline $\begin{array}{l}\text { Intact rock } \\
\text { strength }\end{array}$ & $\begin{array}{l}\text { Literature values } \\
\text { supplemented by } \\
\text { index tests on core } \\
\text { from geological } \\
\text { drilling }\end{array}$ & $\begin{array}{l}\text { Index and lab testing on } \\
\text { samples from targeted } \\
\text { mine scale drilling; } \\
\text { database established; initial } \\
\text { assessment of lithological } \\
\text { domains }\end{array}$ & $\begin{array}{l}\text { Targeted drilling and } \\
\text { detailed sampling and } \\
\text { lab testing; enhance } \\
\text { database; detailed } \\
\text { assessment and } \\
\text { establishment of } \\
\text { geotech. units for 3D } \\
\text { geotech. model }\end{array}$ & $\begin{array}{l}\text { Infill drilling; } \\
\text { sampling and } \\
\text { lab testing; } \\
\text { refine database } \\
\text { and 3D } \\
\text { geotech. model }\end{array}$ & $\begin{array}{l}\text { Maintenance of } \\
\text { database and } 3 D \\
\text { geotech. model }\end{array}$ \\
\hline $\begin{array}{l}\text { Strength of } \\
\text { structural } \\
\text { defects }\end{array}$ & $\begin{array}{l}\text { Literature values } \\
\text { supplemented by } \\
\text { index tests on core } \\
\text { from geological } \\
\text { drilling }\end{array}$ & $\begin{array}{l}\text { Lab direct shear tests of } \\
\text { saw cut and defect samples } \\
\text { from targeted mine scale } \\
\text { drillholes and outcrops; } \\
\text { database established; } \\
\text { assessment of defect } \\
\text { strength within initial } \\
\text { structural domains }\end{array}$ & $\begin{array}{l}\text { Targeted sampling and } \\
\text { lab testing; enhance } \\
\text { database; detailed } \\
\text { assessment and } \\
\text { establish defect } \\
\text { strengths within } \\
\text { structural domains }\end{array}$ & $\begin{array}{l}\text { Selected } \\
\text { sampling and } \\
\text { lab testing and } \\
\text { refine database }\end{array}$ & $\begin{array}{l}\text { Maintenance of } \\
\text { database }\end{array}$ \\
\hline $\begin{array}{l}\text { Geological } \\
\text { characterisation }\end{array}$ & $\begin{array}{l}\text { Pertinent regional } \\
\text { information; } \\
\text { geotech. assessment } \\
\text { of advanced } \\
\text { exploration data }\end{array}$ & $\begin{array}{l}\text { Assess and compile all new } \\
\text { mine scale geotech. data; } \\
\text { enhance geotech. database } \\
\text { and 3D model }\end{array}$ & $\begin{array}{l}\text { Assess and compile all } \\
\text { new mine scale } \\
\text { geotech. data; enhance } \\
\text { geotech. database and } \\
\text { 3D model }\end{array}$ & $\begin{array}{l}\text { Refine geotech. } \\
\text { database and } \\
\text { 3D model }\end{array}$ & $\begin{array}{l}\text { Maintenance of } \\
\text { geotech. } \\
\text { database and 3D } \\
\text { model }\end{array}$ \\
\hline
\end{tabular}

In general terms, as a project moves forward, uncertainty is reduced with the increased level of database detail. Data requirements vary between projects based on the size and geological complexity of a site as well as other considerations such as how risk adverse the owner is, regional socio-economic/socio-political influences of the project location and proximity to existing projects.

These increasingly detailed data, in conjunction with empirical, analytical and numerical design tools, can then be used to create, and advance, ground behaviour predictive models. 
Table 2 Geotechnical classification of mining projects from Haile (as cited in Dunn et al. 2011)

\begin{tabular}{|c|c|}
\hline \multirow{4}{*}{$\begin{array}{l}\text { Implied } \\
\text { (inferred) }\end{array}$} & Geotechnical model has a low level of reliability \\
\hline & Based on global estimates of geotechnical characteristics \\
\hline & $\begin{array}{l}\text { Will enable only a limited scope of analysis, and development of only conceptual level, mine-wide design } \\
\text { parameters }\end{array}$ \\
\hline & $\begin{array}{l}\text { Variability or uncertainty in the geotechnical model could have a significant impact on the economic viability } \\
\text { of the project }\end{array}$ \\
\hline \multirow{4}{*}{$\begin{array}{l}\text { Qualified } \\
\text { (indicated) }\end{array}$} & Geotechnical model has a reasonable level of confidence \\
\hline & Provides a broad indication of the intrinsic spatial variability of the geotechnical characteristics \\
\hline & $\begin{array}{l}\text { A reasonable scope of analysis could be applied, which broadly defines geotechnical domains, enabling the } \\
\text { development of reasonable reliable, domain-specific design parameters }\end{array}$ \\
\hline & $\begin{array}{l}\text { Variability or uncertainty in the geotechnical model could have a moderate impact on the economic viability } \\
\text { of the project }\end{array}$ \\
\hline \multirow{4}{*}{$\begin{array}{l}\text { Justified } \\
\text { (measured) }\end{array}$} & Geotechnical model has a high level of confidence \\
\hline & Provides a good indication in the intrinsic spatial variability of the geotechnical characteristics \\
\hline & $\begin{array}{l}\text { A comprehensive scope of analysis could be applied to well-defined geotechnical domains enabling the } \\
\text { development of domain-specific mine design parameters }\end{array}$ \\
\hline & $\begin{array}{l}\text { Variability of uncertainty in the geotechnical model would not significantly affect the economic viability } \\
\text { of the project }\end{array}$ \\
\hline \multirow[t]{3}{*}{ Verified } & Geotechnical model is based on in situ knowledge of the rock mass \\
\hline & $\begin{array}{l}\text { Provides a reliable model of the intrinsic variability of geotechnical characteristics. Performance of the } \\
\text { recommended design parameters have been verified through historical experience from neighbouring } \\
\text { excavations and/or interim staged pit slopes }\end{array}$ \\
\hline & $\begin{array}{l}\text { The design has been demonstrated to be practical and achievable. Variability or uncertainty in the } \\
\text { geotechnical model would not adversely affect either the operational or economic viability of the project }\end{array}$ \\
\hline
\end{tabular}

\section{Geotechnical data}

Intact rock strength as well as fracture shear strength may be estimated by field estimates of strength or quantified by sophisticated laboratory testing. Index estimates provide a first approximation during scoping level studies and are augmented by laboratory testing as a project evolves, however, index testing should be continued over a project life. Field estimates of strength should be routinely collected by a geotechnical engineer or technical personnel trained in rock mechanics. This will add (admittedly somewhat subjective) value to the database and, more importantly, gives site staff more intimate and practical knowledge of ground conditions and the range of variability in their mine.

Rock mass characterisation is achieved by data collected through geotechnical core logging and mapping campaigns. At the scoping level this may be as simple as a high level inspection of non-oriented core for preliminary estimates of rock mass classification. Orientated core (or non-orientated complimented by down hole televiewer surveys) is typical for prefeasibility and feasibility level studies where structural orientations become increasingly pertinent to reducing design uncertainty. Where outcrops and/or underground development is available, geotechnical mapping must also be conducted.

In addition to collecting conventional geotechnical parameters, data regarding ground reactions can be collected during operation as a check on the geomechanical assumptions made as part of mine planning and geotechnical domaining. Behaviour mapping that can be incorporated into such a model includes:

- Damage mapping: document where the rock mass and ground support elements are incurring damage, or not. Quantitative guidelines regarding the intensity of damage need to be established, to reduce subjectivity. Damage mapping criteria may be site specific, however, the criteria should be quantified by the percentage of area influenced by damage, the depth of damage, and the support condition; Figure 1 provides a good example. An additional example, more specific to squeezing ground, can be found in Fernandez et al. (2012). 


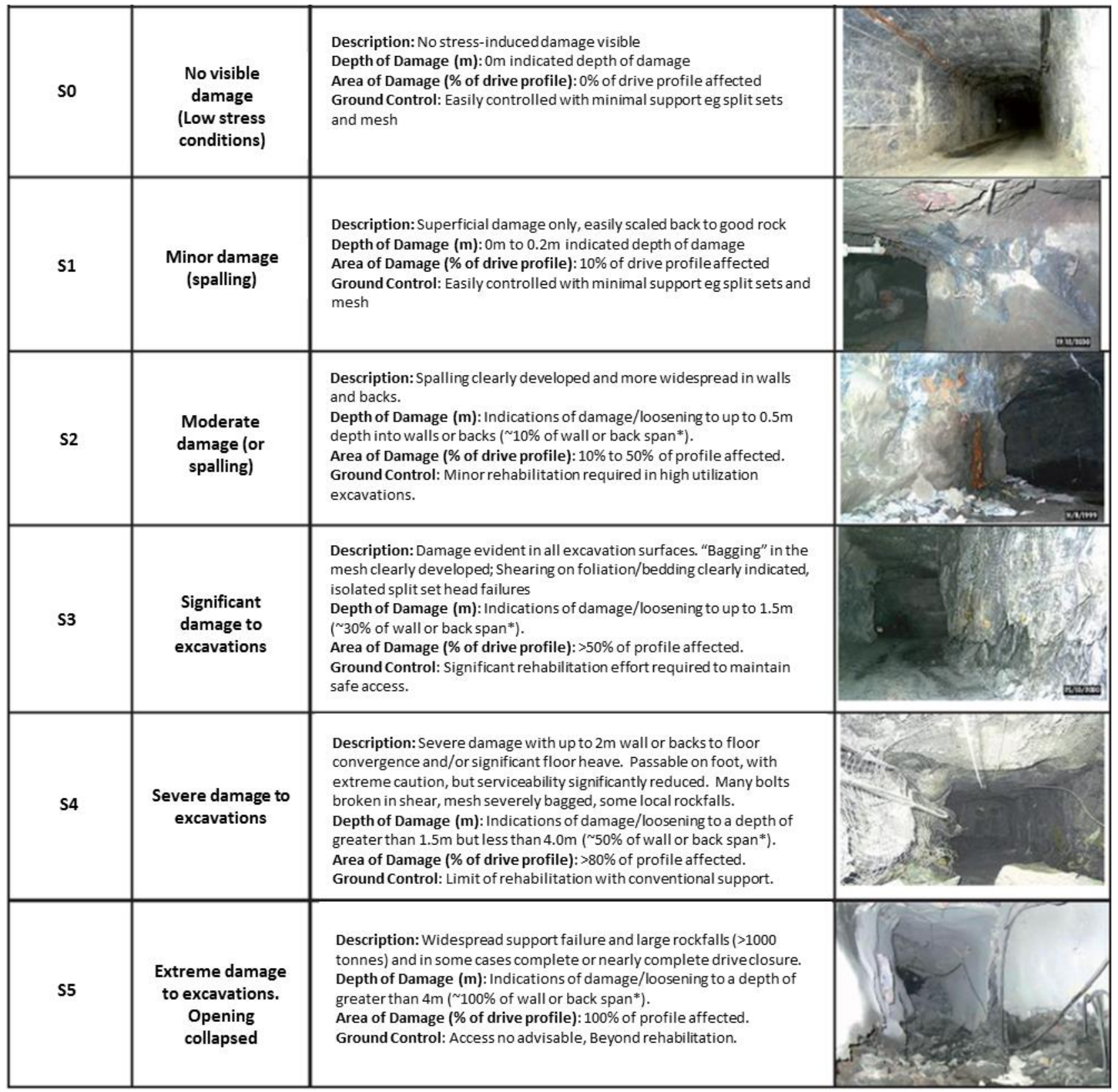

Figure 1 Example of ground response categories (damage mapping — Sandy et al. 2010)

- Mechanism mapping: this captures the type of damage and failure mechanism. In some cases it is not sufficient to document rock mass strength and damage intensity because similar rock masses under different loading regimes will respond in different manners. Figure 2 provides an excellent example; here two areas of the same mine have identical rock mass ratings (RMR) and structural conditions (joint set orientations, spacing, persistence and character). Both areas have been subject to damage of similar intensity. However, the mechanisms (driven by near field stress conditions) are entirely different and the ground support strategy required to stabilise these conditions is completely different as well. Different mechanisms require different design strategies, and in the absence of understanding the 'why' it is impossible to make informed decisions around mine planning. This leads to significant risk to mine safety and economics.

- Pull test data: The spatial distribution of pull test results may indicate poorer performance of bolts in certain ground conditions or regions of a mine. It is not sufficient to simply define a percentage passing or average load achieved by all pull tests completed throughout the mine. Pull test data should be represented within a three-dimensional (3D) geotechnical model for result visualisation, 
and should be stringently evaluated against numerous factors including rock type, rock mass quality, alteration, groundwater, support age, rehabilitation records etc.

- Ground water data: locations and flow rates of ground water may be indicators of geological features, damage zones etc.

- Ground water chemistry (particularly important for sites with corrosive groundwater): identify locations where chemistry could contribute to accelerated corrosion.

- Overbreak/underbreak during development.

- Falls of ground.

- Conventional instrumentation and seismic monitoring: instrumentation and microseismic monitoring provide invaluable quantitative geotechnical data. A detailed review of instrumentation and techniques is not provided here as there are many excellent resources available on this topic.

Mechanism: Vertical major principal stress contributes to abutment loading and squeezing of ribs while loss of confinement in the back results in bulking.
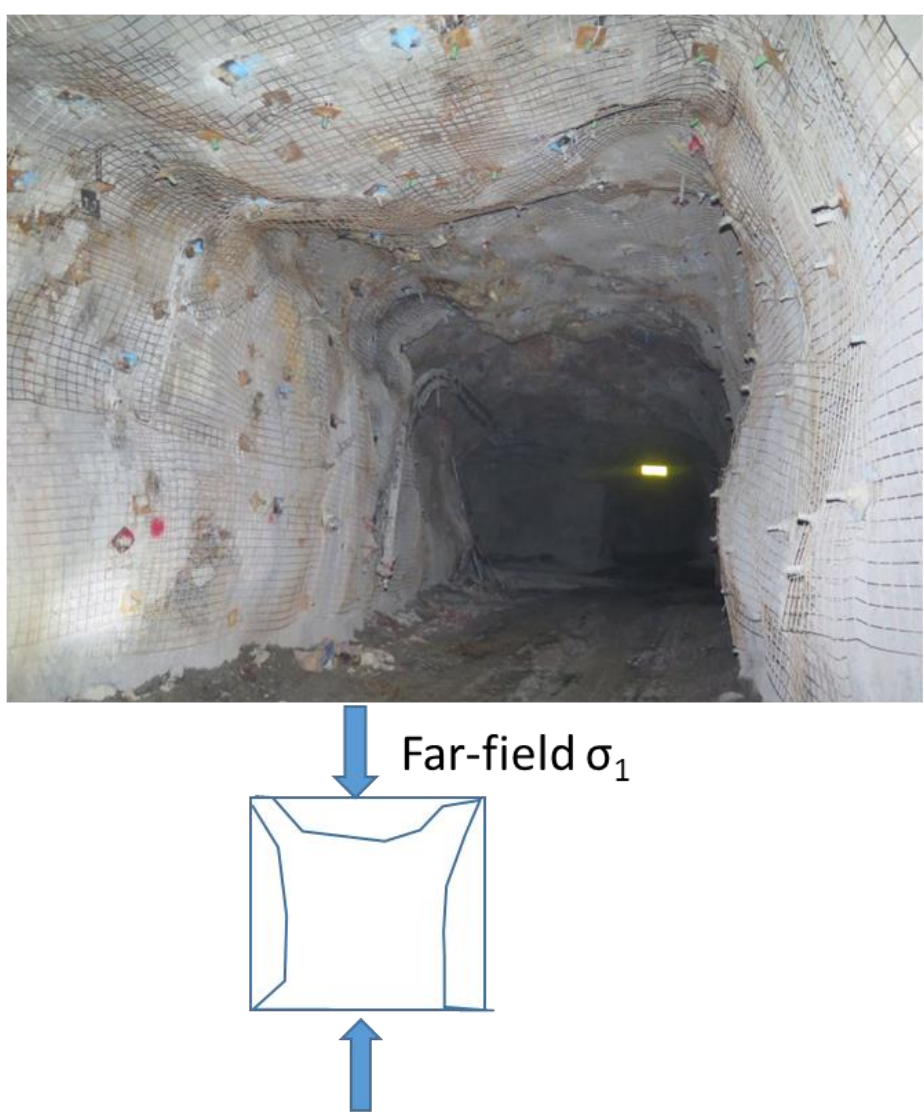

Mechanism: A local rotation in the major principal stress induces shear failure in the back, while ribs incur no damage.
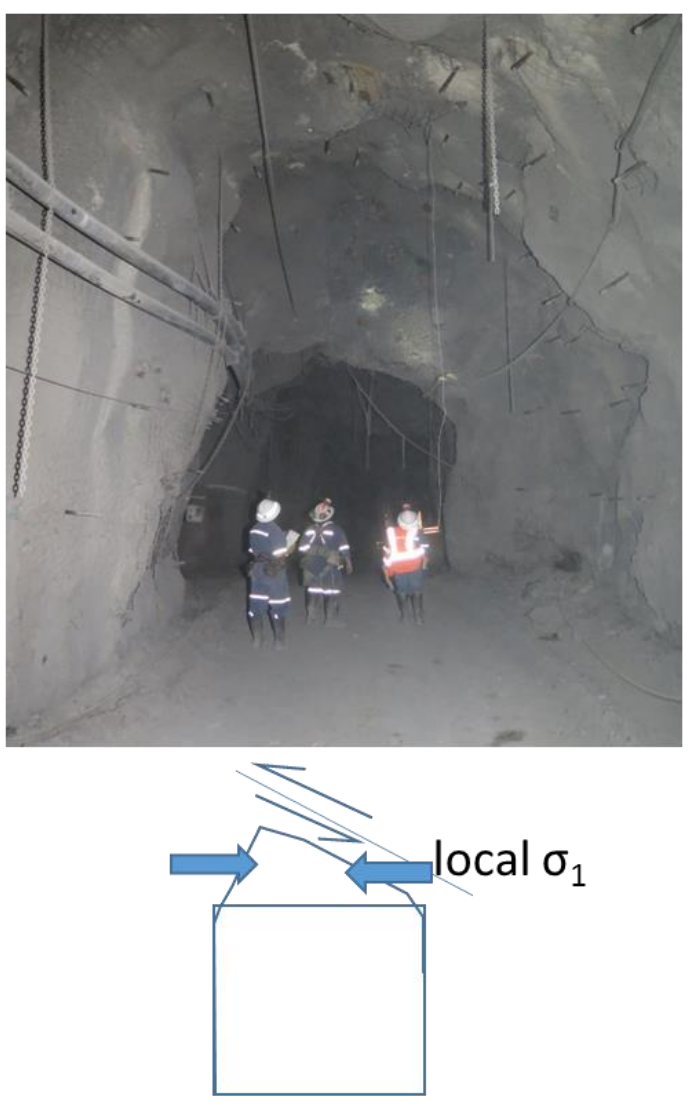

Figure 2 Significantly different ground reactions where rock mass quality and joint distributions are nearly identical due to local variation in in situ stress conditions

It is important to note that these data need to be collected on a regular basis. The appropriate frequency of data collection can vary drastically between specific situations and data types. It should be noted that, damage mapping and other databases should be updated regularly; this may be as frequent as daily or weekly in active, high risk, mining areas or once or twice a year in low risk or quiet areas of a project.

While geotechnical data collection is (generally) given reasonable priority during design studies, the continued collection of geotechnical data over project life is often neglected, despite the general consensus amongst practitioners that routine data collection is best practice. Or, if data is collected, it is subsequently 
ignored. This neglect of best practice may be attributed to various factors and situations. Most commonly, in the opinion of the authors, this is due to a combination of: (1) low priority given by site personnel due to overwhelming demands on their time; and (2) lack of knowledge as to the application and importance of geotechnical data - particularly amongst mining engineers, who in some cases have very limited exposure to rock engineering over the course of their experience or education.

\section{$4 \quad$ Integrating geological and geotechnical data}

Geotechnical conditions are strongly associated with geological trends - changes in ground behaviour are typically due to changes in rock type and/or location relative to faults and other features, such as intrusions or zones of alteration. Thus, refinements of the geological model should, in turn, result in refinements in the geotechnical data interpretation and modelling. The individual, or department, responsible for geotechnical engineering and ground control at a site (be it onsite staff or third party consultants) should have a concrete understanding of the site geology (this includes lithology, structures, alterations, mineralisation, and tectonic history). This is not a short order, however, it is, in the opinion of the authors, critical to the intelligent interpretation of geotechnical data and conditions, and fundamental to making informed interpretations of expected ground behaviour. Failure to understand and utilise a site geological model can result in unforeseen changes in ground behaviour. When changes in ground behaviour are not anticipated, it can be costly if conditions either improve (over-supporting the ground) or worsen (falls of ground, delays in schedule). For projects with simple geology, it may be safe to assume relatively uniform conditions, however, when geology is complex, it is likely that earlier, more data-limited phases of project development were not able to fully capture the variability in ground conditions and resultant rock behaviour. It is the authors opinion that the historical (and ongoing) poor communication between the geology and mining engineering departments is a key factor inhibiting optimal geotechnical interpretations and predictions, resulting in increased geomechanical risk to operations.

\section{Data representation and usage}

The vast amount of geotechnical data collected through the life of a project is meaningless unless it can be used effectively for optimising design, risk identification and mitigation, as well as project planning. The large amount of data requires interpretation, and this task can be made easier by using specific techniques for data representation.

Figure 3 demonstrates two distinct levels of detail for geotechnical data interpretation. First, the three rock units have binned ranges of rock mass quality. Second, the same three rock units distributed across two geotechnical domains are given a statistical distribution of rock mass quality as provided by cumulative distribution curves. The binned ranges are appropriate only for scoping to prefeasibility level studies, while the statistical distribution of rock mass quality is recommended by the authors for any project at feasibility level or beyond. Once a project reaches feasibility level there should be sufficient data to statistically distinguish rock mass quality. 
Binned Rock Mass Quality

\begin{tabular}{|c|c|}
\hline Rock Type & RMR \\
\hline Litho A & $61-66$ \\
\hline Litho B & $55-61$ \\
\hline Litho C & $47-53$ \\
\hline
\end{tabular}

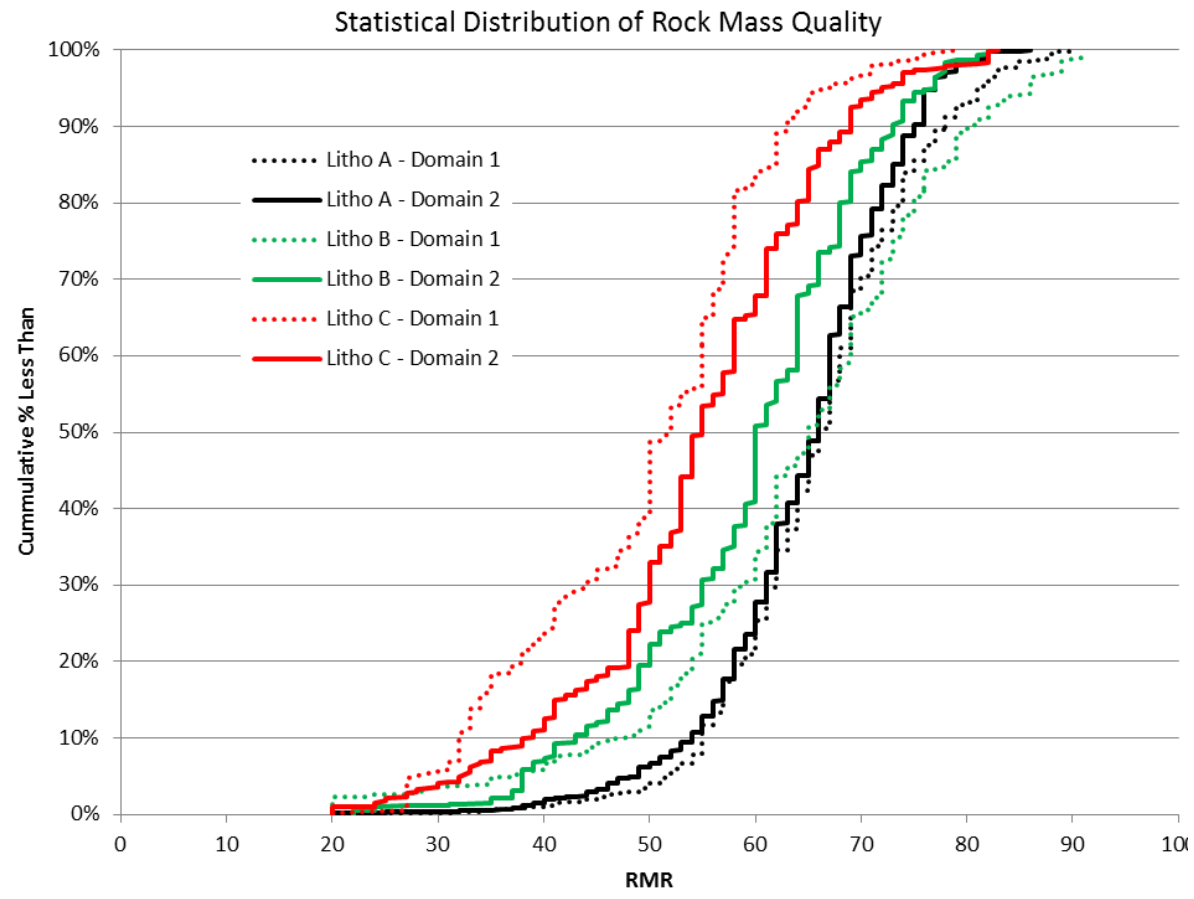

Figure 3 Example data representation for interpretation using (top) binned ranges - appropriate for scoping or prefeasibility studies, and (bottom) statistical representation of rock mass quality required for feasibility design and onwards

The statistical representation of data, as demonstrated in Figure 3 , is valuable for quantifying risk. Consider that the feasibility level ground support design (intended for costing purposes) may be defined by a 30th to 50th percentile of rock mass quality. However, it is also possible to then say that project budgeting should account for added support cost and/or reduced development rates for lower bound rock mass conditions. For example, using the data displayed in Figure 3, say that where RMR is less than 40 , shotcrete must be utilised in addition to a standard bolting and screening pattern. With this representation of data we can now quantify that for feasibility level costing, the added shotcrete costs would be necessary for $4 \%$ of development in the Litho A - Domain 1 and $25 \%$ of development in Litho C - Domain 1 . We can also budget for reduced advance rates due to both shorter rounds and the time allotment for the application of shotcrete. This process of evaluation ultimately reduces project risk because the geotechnical risks and opportunities can be better quantified.

At the operational level, the geotechnical database should be sufficiently detailed to provide geotechnical domains to the mine design. Geotechnical domaining should be used to create geotechnical hazard maps where-by the anticipated ground conditions can be visually communicated to managers, engineers and operators (for example Figure 4). 


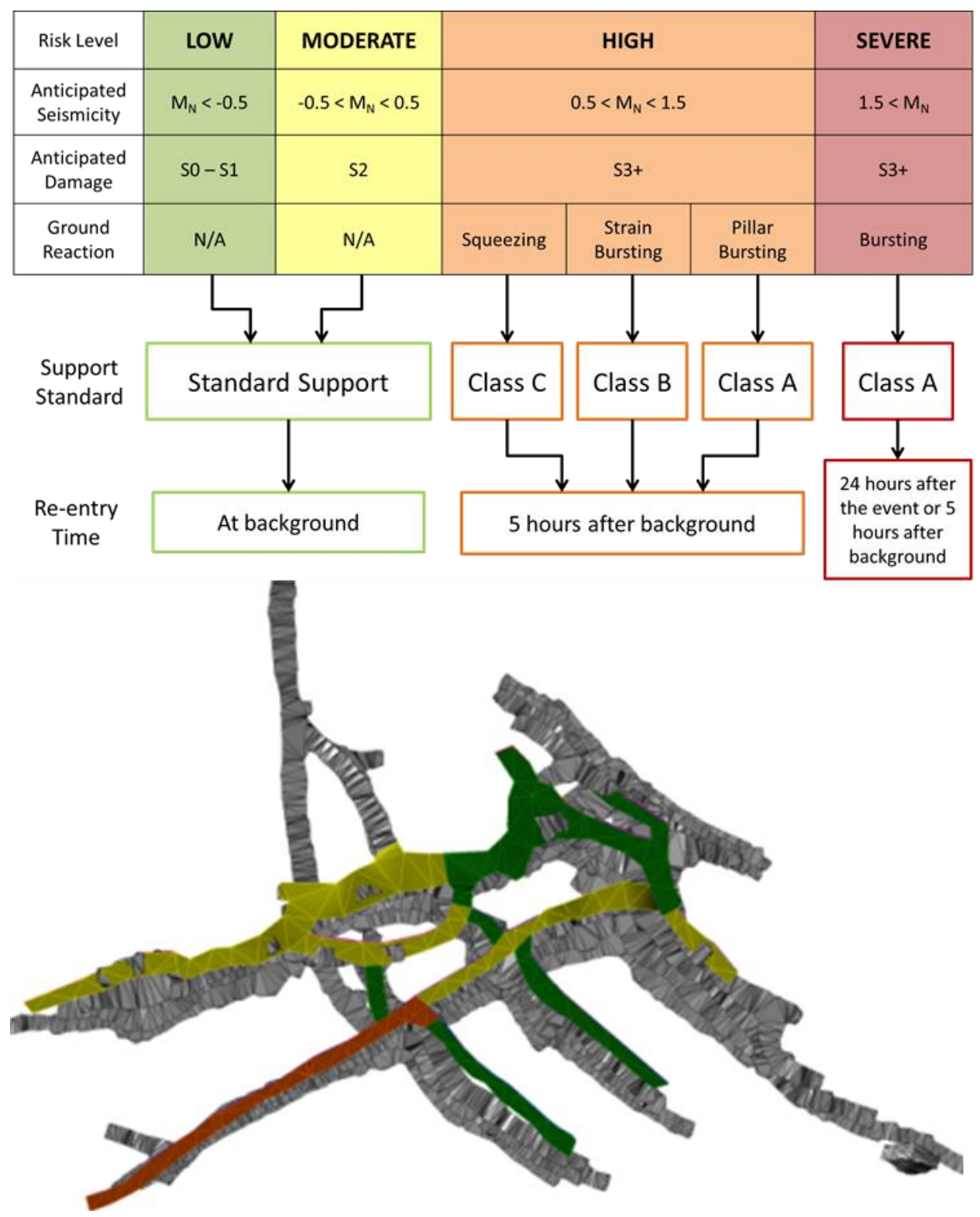

Figure 4 Geotechnical hazard mapping where risk, mechanism, and design criteria are specified. In this case seismic risk is utilised as an example, however, the concept is applicable to any risk situation

\section{Three-dimensional representation of geotechnical data}

All geotechnical and ground behaviour data should be compiled in a 3D model that enables information to be filtered and queried. Data in this model should include the following, as appropriate:

- Raw geotechnical data - digitised mapping, core log database.

- Geotechnical model - interpreted domains.

- Lithology model.

- Structural model.

- Alteration model.

- Mine as-built geometries and design shapes.

- Instrumentation data. 
- Seismic data.

- Pull test results.

- Digitised damage mapping and mechanism mapping.

- FOG geometries.

- Water - zones of high inflows and/or adverse chemistry.

Figure 5 shows a plan view from a 3D model incorporating many of the previous elements. In this screenshot, zones of moderate, strong and very strong alteration, and the locations of intrusives, are shown relative to drift overbreak that occurred during development. In this case, overbreak during development does not present an immediate safety risk, however, there are financial and scheduling implications related to cycle time and material transport. We can see that overbreak aligns well with intrusives striking northwest-southeast and zones of very strong alteration. Once this relationship is established, procedures for identifying and excavating through those specific zones can be optimised for this mine. Identifying this type of relationship may appear to be obvious, however, in many mines, with the rapid application of shotcrete at the face and sparse geotechnical mapping, these seemingly obvious correlations are all too commonly missed. The correlation of variances in ground behaviour (intensity and mechanisms) to geological controls presents significant safety and economic opportunities for design optimisation.

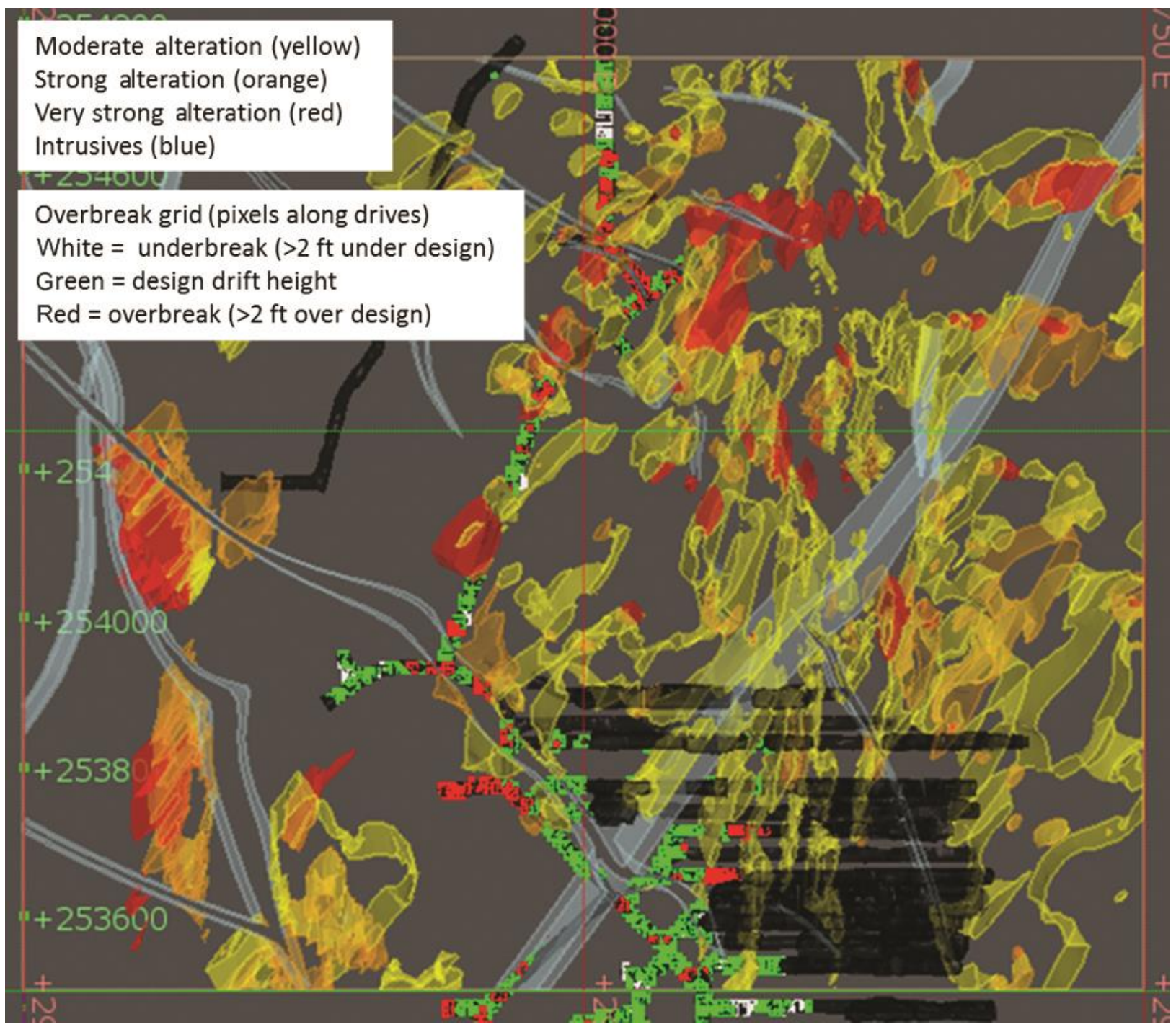

Figure 5 Plan view of 3D model showing alteration zones, intrusives and development overbreak 
Further, 3D ground models enable practitioners to undertake statistical evaluations of geotechnical domains to provide quantified assessment of risk. It is recommended that software be used that can run evaluations (numerous geological modelling software packages exist and their functionality is applicable to geotechnics). The use of statistics in the analysis and interpretation of ground behaviour for the quantifying hazards and their probability of occurrence by domain has proven useful for the authors.

\section{Design verification}

The final step of developing a geotechnical model is verification - a process that (like data collection) should be ongoing throughout project operation. Up to this point, the discussion provided by this paper has been focussed on what geotechnical data should be collected at given phases of the project, and how to effectively interpret and utilise it for optimising design and the communication of risk. Once a design is implemented, verification of the predicted ground response must be completed by back-analysis to determine if the expected performance (of both the rock and the ground support elements) has been achieved. Adjustments to the geotechnical model may be made at this point depending on the outcomes of the verification process.

Geotechnical designs are inherently data limited, particularly in mining applications, with considerable uncertainty in geotechnical design parameters. These inherent uncertainties contribute to elevated geotechnical risk. Data uncertainty and associated risks can be mitigated by the continuous and targeted observation of ground response and associated performance of designs as mining progresses and the information becomes available. Design verification relies on qualitative and quantitative observations, which range from visual observations to sophisticated instrumentation programs. These observations are used to enhance the understanding of the geomechanical model and optimise the design strategy for future mining. Observational engineering has been common within the discipline of geotechnical engineering even before it was first documented by Peck (1969), who described the general principal that allows for modifications to a project's design as more information becomes available as said project progresses.

\section{Concluding remarks}

The intent of this discussion has been to demonstrate techniques for optimising the use of and communicating geotechnical data. The collection of geotechnical data is a time-consuming endeavour, which endures a project life from scoping study stages right through to the end of mine life. The capital investment in geotechnical data over a project life can be substantial and, in the opinion of the authors, the full potential for geotechnical data to add value to a mining project is commonly not achieved. Effective use of geotechnical data (site characterisation data, instrumentation data, ground response data, among others) provides many opportunities such as: optimised allocation of resources for future data collection (type of data, where to target etc.); enables geotechnical staff to communicate conditions to managers, engineers and operators; quantification of geotechnical risk (probability of occurrence); and, quantification of resource allocation for risk mitigation.

\section{References}

Dunn, MJ, Basson, FR \& Parrott, TT 2011, 'Geotechnical data-a strategic or tactical issue', in Y Potvin (ed.), Proceedings of the Fourth International Seminar on Strategic versus Tactical Approaches in Mining, Australian Centre for Geomechanics, Perth, pp. 21-39.

Fernandez, F, Watt, G \& Ooi, J 2012, 'Strategic management for squeezing ground conditions at the Argyle Diamonds block cave project', Australian Journal of Civil Engineering, vol. 10, no. 2, pp. 193-206.

Peck, RB 1969, 'Advantages and limitations of the observational method in applied soil mechanics', Geotechnique, vol. 19, no. 2, pp. 171-187.

Sandy, M, Sharrock, G, Albrecht, J \& Vakili, A 2010, 'Managing the transition from low stress to high stress conditions', in P Hagan \& S Saydam (eds), Proceedings of the Second Australian Ground Control in Mining Conference, The Australasian Institute of Mining and Metallurgy, Carlton South.

Stacey, P 2009, 'Fundamentals of slope design', in J Read \& P Stacey (eds), Guidelines for Open Pit Slope Design, CSIRO Publishing, Clayton, Victoria, p. 13. 